\begin{tabular}{|l|l|l||}
\hline \multicolumn{2}{|c|}{ PublisherInfo } \\
\hline \hline PublisherName & $:$ & BioMed Central \\
\hline \hline PublisherLocation & $:$ & London \\
\hline \hline PublisherImprintName & $:$ & BioMed Central \\
\hline \hline
\end{tabular}

\title{
Pneumococcus genome
}

\begin{tabular}{||l|l|l||}
\hline \multicolumn{2}{|c||}{ ArticleInfo } \\
\hline \hline ArticleID & $:$ & 4154 \\
\hline \hline ArticleDOI & $:$ & $10.1186 /$ gb-spotlight-20010720-01 \\
\hline \hline ArticleCitationID & $:$ & spotlight-20010720-01 \\
\hline \hline ArticleSequenceNumber & $:$ & 225 \\
\hline \hline ArticleCategory & $:$ & Research news \\
\hline ArticleFirstPage & $:$ & 1 \\
\hline \hline ArticleLastPage & $:$ & 2 \\
\hline \hline & $:$ & RegistrationDate : 2001-07-20 \\
ArticleHistory & $:$ & OnlineDate $:$ 2001-07-20 \\
\hline \hline ArticleCopyright & $:$ & BioMed Central Ltd2001 \\
\hline \hline ArticleGrants & $:$ & \\
\hline \hline ArticleContext & $:$ & 130592211 \\
\hline \hline
\end{tabular}




\section{Jonathan B Weitzman}

Email: jonathanweitzman@hotmail.com

Streptococcus pneumoniae (pneumococcus) was the bacterial strain used in the historic studies of Avery, MacLeod and McCarty more than half a century ago to demonstrate that DNA is the material of inheritance. The Gram-positive bacterium causes over 3 million infant deaths each year from pneumonia, bacteremia and meningitis. In the July 20 Science, Tettelin and colleagues from The Institute for Genome Research (TIGR) report the complete genome sequence of S. pneumoniae (Science 2001, 293:498-506). The genome is a single circular chromosome, 2.1 megabases long with a GC content of $39.7 \%$. They identified 2,236 putative genes, many of which (64\%) could be assigned a biological function. About half of the predicted proteins were most similar to proteins from other lowGC Gram-positive species, while $20 \%$ of the genes did not match genes in the databases. The $S$. pneumoniae genome is rich in insertion sequences (about $5 \%$ of the genome). The genome encodes many ATP-dependent transporters and sugar transporters (30\% of transporters), which may reflect its adaptation to sugar-rich environments such as the oral cavity. Iron and phosphate transporters may also contribute to virulence. Pathogenicity may be influenced by extracellular enzyme systems that control the metabolism of polysaccharides and hexosamines, and by a 13-gene cluster involved in capsular biosynthesis. Sixty-nine proteins are predicted to be expressed on the bacterial surface and the authors identified a putative signal peptide motif. Tettelin et al. predict that further comparative analysiswill highlight genes regulating virulence and pathogenicity and indicate candidate vaccine targets.

\section{References}

\section{Science, [http://www.sciencemag.org]}

2. The Comprehensive Microbial Resource (CMR), [http://www.tigr.org/tigr-scripts/CMR2/ CMRHomePage.spl]

3. The Institute for Genome Research, [http://www.tigr.org]

4. Mosaic genes and mosaic chromosomes: intra- and interspecies genomic variation of Streptococcus pneumoniae. 